\title{
Natural Resource Management Schemes as Entry Points for Integrated Landscape Approaches: Evidence from Ghana and Burkina Faso
}

\author{
Samson Foli $i^{1} \cdot$ Mirjam A. F. Ros-Tonen ${ }^{1} \cdot$ James Reed $^{2} \cdot$ Terry Sunderland $^{2}$
}

Received: 12 September 2016 / Accepted: 8 April 2017 / Published online: 20 April 2017

(C) The Author(s) 2017. This article is an open access publication

\begin{abstract}
In recognition of the failures of sectoral approaches to overcome global challenges of biodiversity loss, climate change, food insecurity and poverty, scientific discourse on biodiversity conservation and sustainable development is shifting towards integrated landscape governance arrangements. Current landscape initiatives however very much depend on external actors and funding, raising the question of whether, and how, and under what conditions, locally embedded resource management schemes can serve as entry points for the implementation of integrated landscape approaches. This paper assesses the entry point potential for three established natural resource management schemes in West Africa that target landscape degradation with involvement of local communities: the Chantier d'Aménagement Forestier scheme encompassing forest management sites across Burkina Faso and the Modified Taungya System and community wildlife resource management initiatives in Ghana. Based on a review of the current literature, we analyze the extent to which design
\end{abstract}

Samson Foli

s.k.foli@uva.nl

Mirjam A. F. Ros-Tonen

m.a.f.ros-tonen@uva.nl

James Reed

j.reed@cgiar.org

Terry Sunderland

t.sunderland@ cgiar.org

1 Department of Geography, Planning and International Development Studies and Centre for Sustainable Development Studies, University of Amsterdam, P.O. Box 15629 Amsterdam 1001 NC, The Netherlands

2 Center for International Forestry Research (CIFOR), Jalan CIFOR, Situ Gede, Bogor, West Java 16115, Indonesia principles that define a landscape approach apply to these schemes. We found that the CREMA meets most of the desired criteria, but that its scale may be too limited to guarantee effective landscape governance, hence requiring upscaling. Conversely, the other two initiatives are strongly lacking in their design principles on fundamental components regarding integrated approaches, continual learning, and capacity building. Monitoring and evaluation bodies and participatory learning and negotiation platforms could enhance the schemes' alignment with integrated landscape approaches.

Keywords Natural resource management $\cdot$ Landscape approach $\cdot$ CREMA $\cdot$ Modified taungya system $\cdot$ Chantier d'Aménagement Forestier

\section{Introduction}

In sub-Saharan Africa, close to 600 million people are dependent on forests for food and/or income, and many of those are food insecure (Ickowitz et al. 2014; Koffi et al. 2016). Facing insecurities related to forest decline, loss of biodiversity and erosion of ecosystem services, many are also vulnerable to the impacts of climate change (Bele et al. 2015; Mantyka-Pringle et al. 2015). Recent environmental discourse calls for the integrated governance of natural resources and integrating conservation efforts with opportunities for rural economic development and increased resilience to climatic vicissitudes (Sachs et al. 2009; Scherr et al. 2012; Minang et al. 2014; Sunderland et al. 2015).

An integrated landscape approach is a framework that attempts to reconcile social, environmental, and economic development with biodiversity conservation and climate change mitigation (Kozar et al. 2014). Although seen as a 
departure from sectoral approaches to land management, rather than seeking elusive win-win outcomes, landscape approaches recognize that trade-offs between socioeconomic and ecological objectives can-and will-occur. Several authors have developed principles and tools that can guide research and decision-making on multifunctional landscapes (Sayer et al. 2013; Ros-Tonen et al. 2014; Reed et al. 2015; Chia and Sufo 2016), yet it remains unclear how these principles can be fully operationalized in specific contexts (Reed et al. 2017).

Furthermore, a natural resource governance approach that recognizes multiple and often competing land uses and manages the trade-offs between them is complex, time- and cost-intensive (Reed et al. 2015, 2016) and long-term funding poses a challenge (Hart et al. 2014). Identifying locally embedded natural resource management (NRM) initiatives that can provide entry points for integrated landscape approaches offers potential to overcome some of these implementation challenges. Reviewing one NRM scheme in Burkina Faso and two in Ghana, this paper aims to highlight whether, and how, differing NRM initiatives that integrate landscape and livelihood objectives of local populations can provide such entry points. Hence this paper asks, to what extent do three locally embedded resource management initiatives in Burkina Faso and Ghana align with the fundamental design principles of integrated landscape approaches and what does this mean for their potential to function as entry points for implementing integrated landscape approaches?

The next section briefly describes the relevant NRM schemes and their importance within their respective local landscape contexts. The methodology section justifies the selection of the cases and details the literature review and analytical framework. The results section analyzes the characteristics of the three schemes along the major design principles for integrated landscape approaches. This serves as a basis for the discussion in which we assess the potential of the schemes to act as entry points for integrated landscape approaches. The conclusion explains the implications of the findings.

\section{Forested Landscapes in Burkina Faso and Ghana: Status and Threats}

Burkina Faso had 5.4 million hectares of forests as of 2015; 95.5\% naturally regenerated and $4.5 \%$ planted forests (FAO 2015, p. 34). Most of Burkina's forests have less than $40 \%$ canopy cover (Paré et al. 2008; Pouliot and Treue 2013) and deforestation ranged between 0.77 and $1.2 \%$ per annum $^{1}$

\footnotetext{
${ }^{1}$ Forest data on Burkina Faso is sparse and inconsistent as a result of different methodologies applied in forestry studies (Westholm and Kokko 2011).
}

from 1990 to 2010 (Ouedraogo 2006; Westholm and Kokko 2011; FAO 2015). Burkina's dry forests constitute a fragmented arable landscape dominated by agroforestry parklands interspersed with deciduous shrub, woody savannah characterized by economically valuable tree species such as shea (Vitellaria paradoxa) and parkia (Parkia biglobosa) (Boffa 1999; Arbonnier 2004; Ky-Dembele et al. 2007). These multifunctional land-use mosaics supply food, fodder, and fuelwood to both rural and urban populations (Ouédraogo 2009; Foli and Rabdo 2016). Trees and nontimber forest products (NTFPs) serve as important food safety nets for the most vulnerable farmers during lean seasons (Koffi et al. 2016). The forested landscape faces pressures of climate-change induced migration flows from the north (Ouedraogo et al. 2010); uncontrolled felling of trees to supply the commercial fuelwood trade; and high fuelwood demand to meet the energy needs of major urban areas (Kabore and Ouedraogo 2000; Ouédraogo 2009).

Ghana's forest cover of $41 \%$ (9.3 million hectares) encompasses primary forest (4.2\%), naturally regenerated forest (92.3\%) and planted forests (3.5\%) (FAO 2015, p. 229). Tree cover decreases from the high forest zone in the south-western third of the country toward the transitional and savannah zones of the north (Derkyi 2012). Forest reserves cover $16.2 \%$ of Ghana's total land area, $80 \%$ of which is production forest designated for timber exploitation, and $20 \%$ as protection reserves for conservation purposes (MLNR 2012). Major threats to the forests are illegal farming, chainsaw logging and-in some areasartisanal and small-scale mining (Derkyi 2012; Hilson 2012). Moreover, national policies have been instrumental to the introduction and intensification of cocoa and, more recently, oil palm (Ros-Tonen et al. 2015), both of which are considered major threats to the remaining forests (Benhin and Barbier 2004; Appiah et al. 2009).

\section{NRM Schemes in Ghana and Burkina Faso Targeting Landscapes and Livelihoods: A Brief Overview}

To address the degradation of forested landscapes, Ghana and Burkina Faso have experimented with several comanagement and community-based NRM initiatives since the 1930s and 1970s, respectively (Agyeman 2006; Murphree 2008; Sawadogo and Tiveau 2011; Asare et al. 2013). These initiatives were established in forest zones with high population pressure where smallholders depend on forests for natural resources.

In Burkina Faso, forest resource management involving rural communities was piloted in 1985 in the Nazinon forest reserve of Sissili Province in the Center-West Region with international donor support and joint implementation by the United Nations Development Program (UNDP) and the Food and Agricultural Organization of the United Nations (project 
UNDP/FAO/BKF/85/011). Offices of the Ministry of Forest and Environment and Sustainable Development (MEDD) were established in the communities and out-posted technicians to provide training on improved methods of tree felling and regenerative coppicing and informing forest management cooperatives (GGF, Groupement de Gestion Forestière). The Chantier d'Aménagement Forestier (CAF) scheme regulates fuelwood harvesting by issuing permits to the forest management groups. Felling permits detail the quantity and type of wood species to harvest from the forest reserve. The revenues of fuelwood trade are distributed on a ratio of 9.1, 13.6, 27.3, and $50 \%$, respectively for the forest tax (harvesting permit), contribution to the village development fund, the forest management fund, and the forest management group members (Ouédraogo 2007; Coulibaly-Lingani et al. 2011). The forest tax supports and staffs CAF offices, whereas the forest management fund supports communities to carry out annual tree planting and monitor the biodiversity of forests (Ouédraogo 2007). Approximately 350,000 ha of forests are currently managed by autonomous unions and cooperative groups under the CAF scheme (Paré et al. 2008; Ouedraogo et al. 2009). In 2012, there were 12 forest management sites (CAFs), involving 473 community forest management groups with 12,000 members officially recognized by the MEDD (2012).

The modified taungya system (MTS) in Ghana is a reforestation scheme launched in 2002 to replace the original taungya introduced in the 1930s in response to rapid forest loss within reserves due to the high demand of forest resources by then colonial authorities (Kalame et al. 2011). The scheme allowed the intercropping of food crops in the early part of the plantation establishment cycle. Approximately 75,000 ha of taungya plantations were established in the 1970s (Agyeman 2006), but the scheme was suspended in 1984 due to a lack of support from farmers who lacked long-term incentives as they were not entitled to shares in timber revenues (Agyeman et al. 2003; Blay et al. 2008; Kalame et al. 2011). The MTS is a co-management arrangement between the Ghana Forestry Commission and local communities and differs from the previous system in that (a) farmers are now entitled to $40 \%$ of the timber proceeds to compensate for their efforts in tree planting, maintenance and protection, and (b) institutions were established to provide farmers a voice in management decisions (Ros-Tonen et al. 2013, 2014; Acheampong et al. 2016). A total of 94,115 ha was planted under the MTS between 2002 and 2009 (FC 2015).

CREMAs were launched in Ghana by the Wildlife Division of Ghana's Forestry Commission ${ }^{2}$ in the early

\footnotetext{
${ }^{2}$ Ghana's Forestry Commissions consists of the Forest Services Division (FSD), the Wildlife Division (WD) and the Timber Industry Development Division (TIDD) and has the Resource Management Support Center (RMSC) as its technical wing.
}

2000s to curtail destruction of wildlife habitats in the country's off-reserve forest areas (Murphree 2008; Asare et al. 2013). The scheme was framed as decentralized and participatory NRM for wildlife conservation and livelihood diversification, while acting as a habitat buffer at the fringes of protected areas and wildlife reserves (Baruah 2015). The guiding principles represent a paradigm shift in Ghana's wildlife policy by giving the local population an increased say over natural landscapes and granting official access to economic benefits from natural resources, thereby recognizing the roles of traditional authorities and women (Asare et al. 2013; WD 2000). There were 26 active CREMAs in 2010 (Asare et al. 2013) and currently over 30 CREMAs in various stages of establishment (Baruah 2015). In total, 313,934 hectares of land are incorporated within CREMA sites, involving 215 communities and satellite communities (Asare et al. 2013).

Further details on the scope of the schemes and actors involved are presented in Table 1.

\section{Materials and Methods}

\section{Selection of Cases}

The three schemes described in the previous section were selected because they were, (1) designed to address landscape degradation while recognizing the long-standing natural resource demands and livelihood objectives of inhabitants, and (2) are the principal NRM schemes in the two countries involving local communities and other stakeholders.

\section{Literature Review}

The literature referred to in this study (national policy documents, project implementation and assessment reports, and peer-reviewed literature) was gathered in four steps. First, gathering peer-reviewed sources involved a search through the Web of Science database, using the names of schemes and their acronyms. Second, additional 'gray literature' was sought using the same keywords in Google Scholar. Publications that focused on the performance and governance aspects of the schemes were selected for further review. Third, unpublished documents were found through the researchers' previous project work in both countries. For Burkina Faso, relevant policy documents and published and unpublished literature was acquired during scoping visits to identify project sites and research partners for the "Sustainable Use of Tropical Forest Biodiversity" project. Similar data on the schemes in Ghana was gathered through long-established contacts with the Wildlife Division and Research Management Support Center-two divisions of 


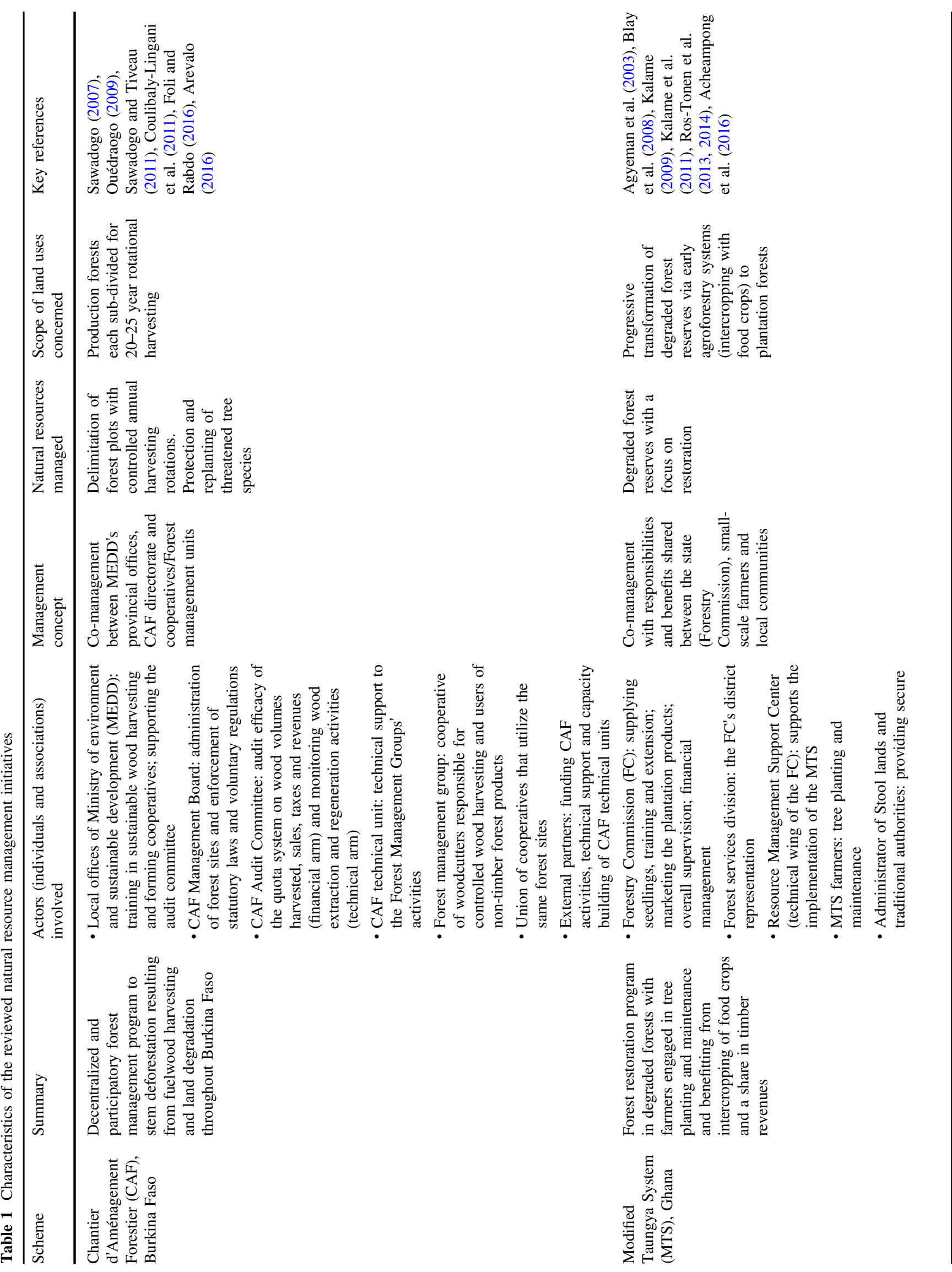




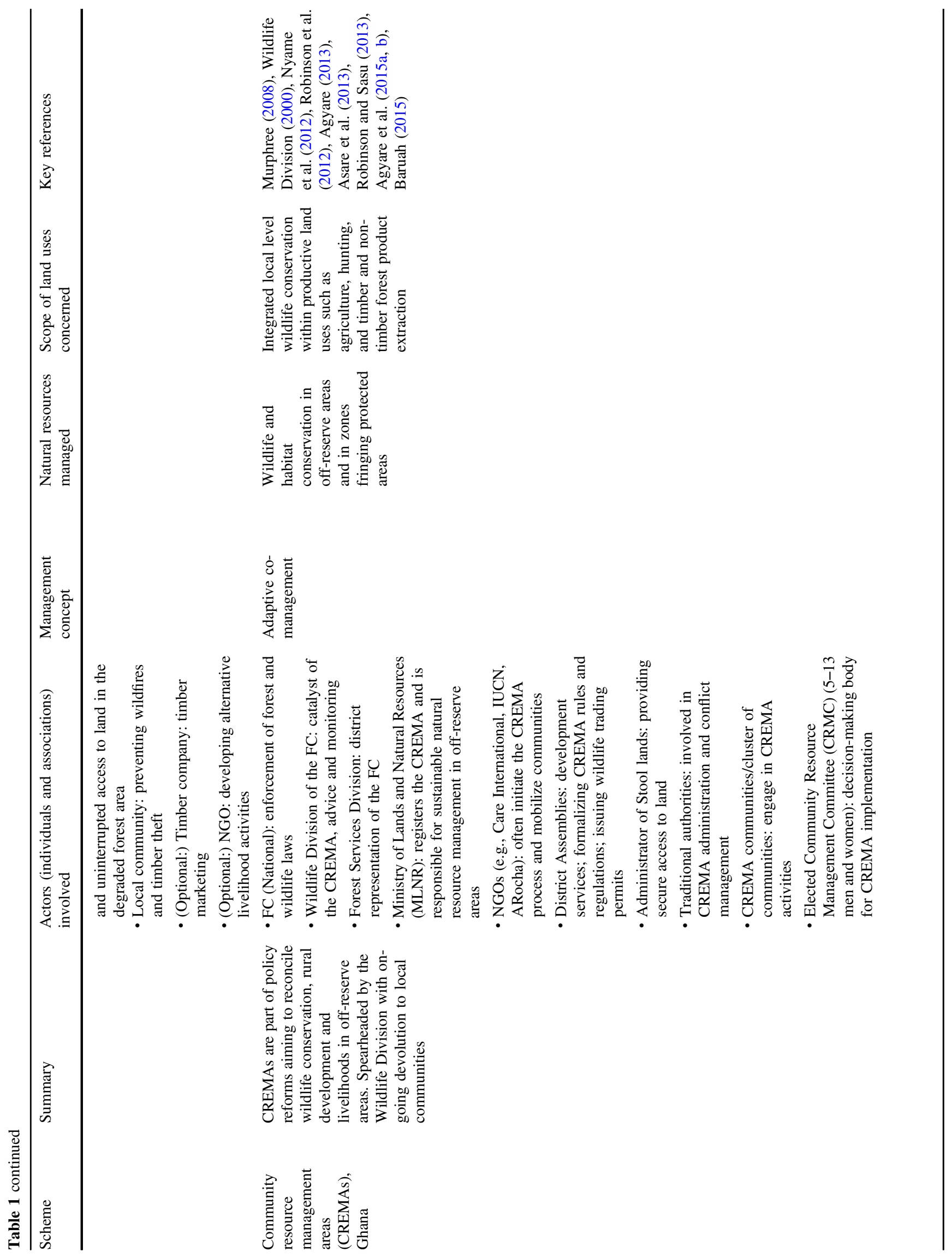




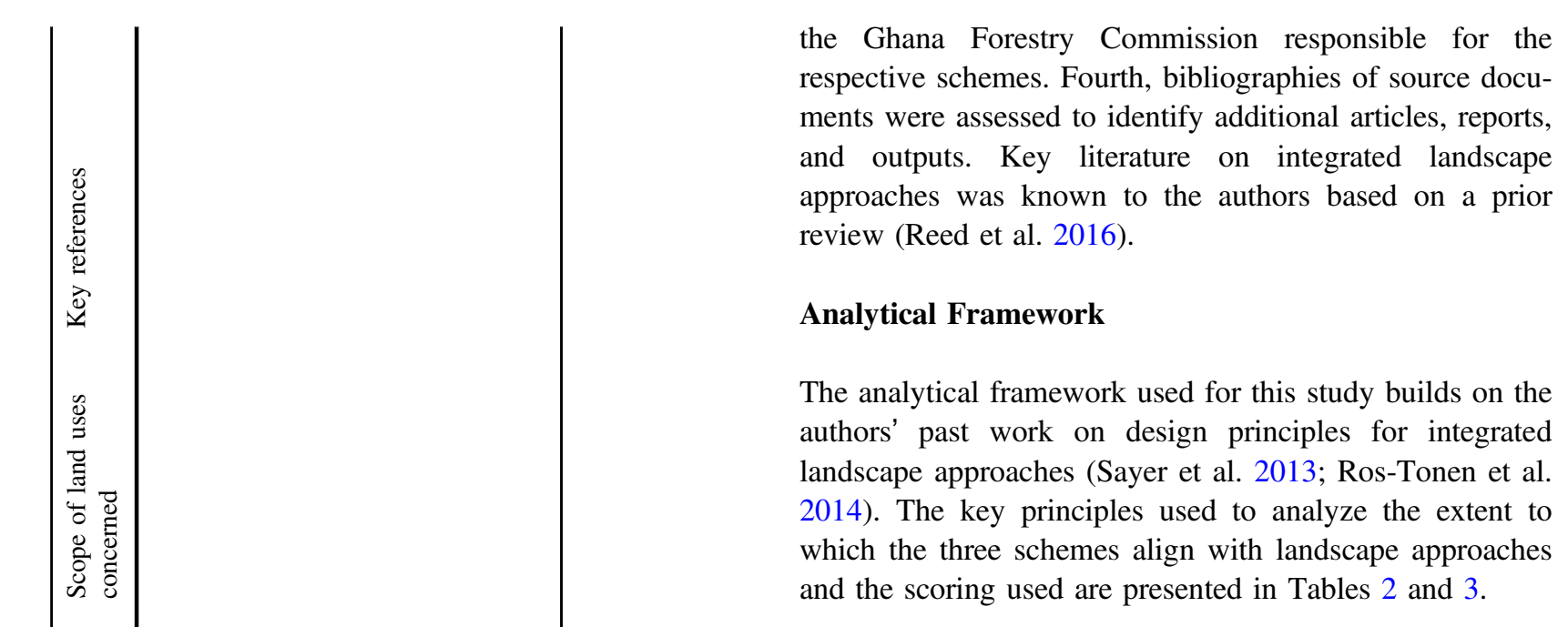

\section{Results}

This section discusses the features of the three NRM schemes along the five design principles highlighted in Table 2.

\section{The CAF \\ Integrated approach}

CAF forests are located within multifunctional parkland agroforestry landscapes that highlight historical integration of forests and food production (Gautier et al. 2015; Westholm 2016). This stems partly from frequent climate vulnerabilities and resource degradation (soil and land degradation) of the region and the search for food safety nets (Koffi et al. 2016). Productive land uses, principally cereal cropping and agro-pastoralism, are often combined with the harvest, processing and sale of wood and NTFPs, which in turn contribute to food security (Boffa 1999; Koffi et al. 2016). Historical importance of forests is emphasized in customary laws that commonly protect important tree species from felling throughout the country (CoulibalyLingani et al. 2011; Ouédraogo 2009). The CAF itself does not explicitly pursue an integrated approach beyond the demarcated production forests set aside for fuelwood extraction.

\section{Adaptive management and continual learning}

CAF was implemented as a co-management scheme of forest between locally chosen representatives, a technical arm and statutory bodies-from the Ministry of Environment down to regional, provincial and the CAF technical body at the district level (Sawadogo 2007; Arevalo 2016). Learning, reciprocity and exchange of information were 


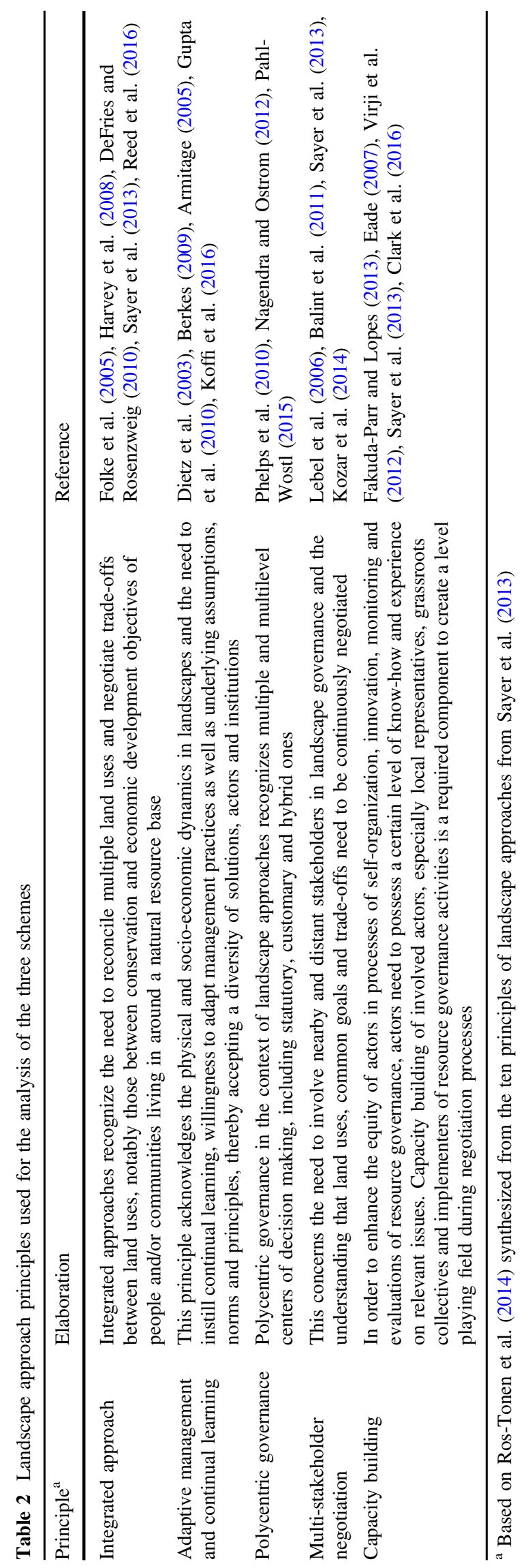

minimal prior to the scheme becoming autonomous in the early 2000s. In the last decade, learning within the CAF has been implemented through research and donor projects targeting forest technicians who support CAF activities and user groups. The latter are predominantly woodcutters who are targeted with updated knowledge regarding felling techniques and directives from the MEDD and women groups supported in setting up tree nurseries and vegetable gardens (Etongo et al. 2015).

\section{Polycentric governance}

Organizational format of CAF schemes involves a variety of actors (Table 1). Forest management groups (GGF) are cooperatives at community level made up of woodcutters autonomously exploiting fuelwood from the demarcated parcels (Coulibaly-Lingani et al. 2011). GGFs utilizing a common CAF parcel (Unité d'Aménagement Forestier) form Unions of Forest Management Groups (UGGFs or Union des Groupements de Gestion Forestière) (Kabore and Ouedraogo 2000). General administration of the CAF is responsibility of the CAF Management Board (Table 1), which ensures compliance with voluntary $\mathrm{CAF}$ regulations, laws of the Forestry Service, and national rules governing cooperatives. The Board comprises presidents of individual forest management groups and unions, appointed by the collective bureaus of UGGFs (Kabore and Ouedraogo 2000). The Board, forest management groups and unions receive support from the CAF Audit Committee in administrating fuelwood quotas, sales, taxes and revenues, and from the Technical Unit for technical matters regarding tree felling, rotation, tree cutting methods, and regeneration (Agbor and Tanyi 2015; Foli and Rabdo 2016). Despite the high complexity, CAF governance maintains a hierarchical structure and therefore does not represent an example of polycentric governance.

\section{Multi-stakeholder negotiation}

CAF groups at district level meet periodically in community-level groups (GGFs) and cooperative unions (UGGFs) and both meet with the Audit Committee annually. Technicians frequently meet with village-level GGFs as part of a biodiversity monitoring routine. Provincial and regional MEDD offices also meet annually to evaluate performance of conservation priorities and to renew objectives. UGGFs are invited to attend, but they usually delegate attendance to the CAF technical director who has the capacity to engage in such meetings. Whether the technical director attends depends on availability of resources. There are no dedicated platforms where all actors of the scheme can collectively negotiate conservation objectives and challenges. Local CAF organizations often request intermediaries - from either CAF Technical Units, 


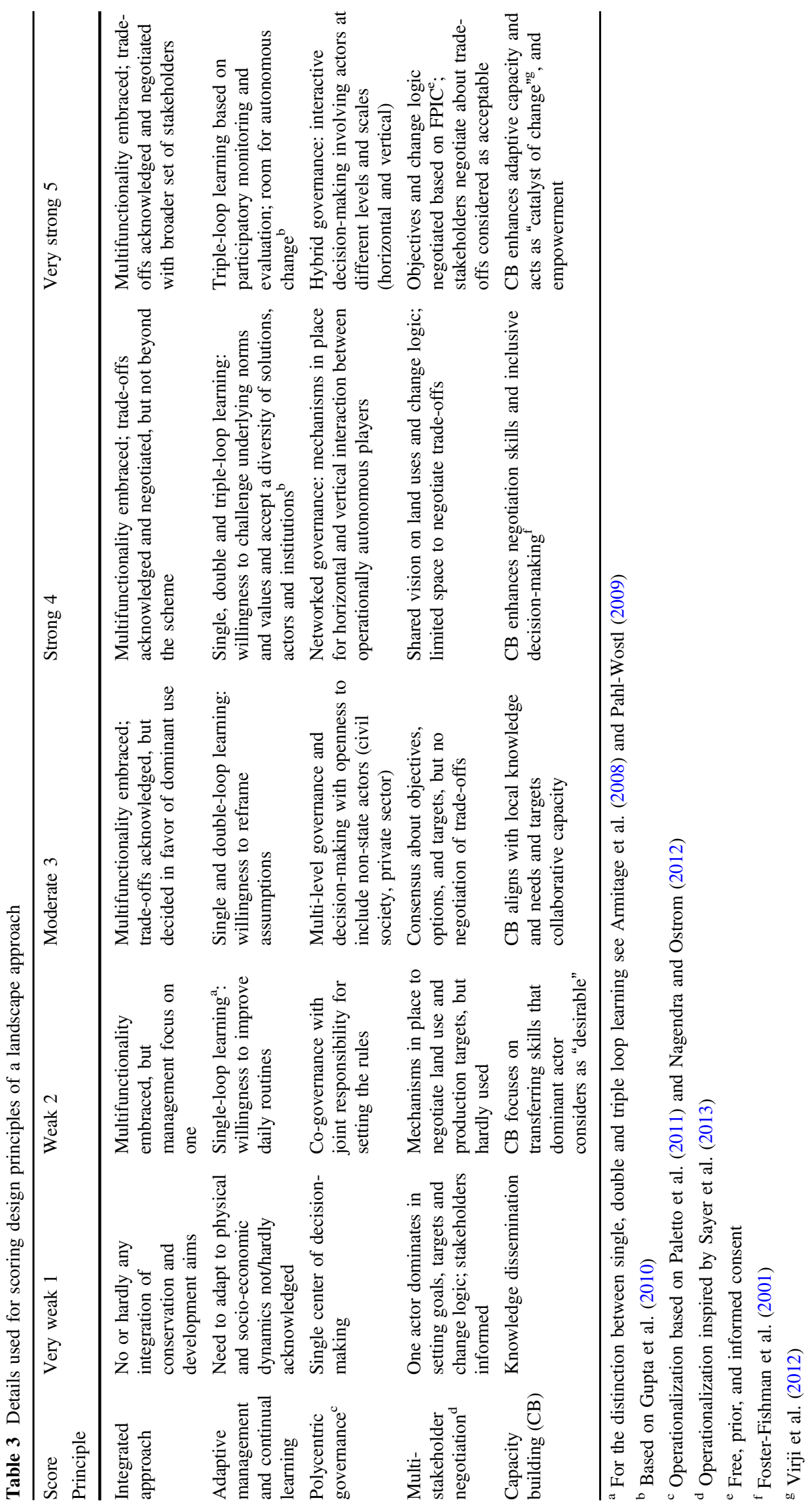


NGOs, or research institutions-to negotiate conservation goals to the regional MEDD on their behalf (Westholm 2016). Hence, negotiation structures are in place, but resources to enable local actors to access discussions at regional and national level are frequently lacking, inhibiting their effective involvement in decision-making concerning forest management.

\section{Capacity building}

Per CAF regulations, technicians receive trainings and refresher conservation education annually, but from record, technicians in the CAF may go for 3 years without receiving new training. The CAF is dependent on external NGO projects for capacity building or trainings on new forest management techniques. There is no explicit focus on capacity building within the CAF beyond the formation of cooperatives and cooperative unions. This limits the capacity of woodcutters and their representatives to negotiate trade-offs of competing land use between them.

\section{The MTS}

\section{Integrated approach}

The MTS exhibits characteristics of an integrated approach by combining timber production, intercropping of food crops, carbon sequestration and climate change adaptation (Kalame et al. 2011; Ros-Tonen et al. 2014; Lasco et al. 2014). Income is derived from the sale of food crops, seedling production and re-investment of revenues in petty trade, resulting in increased food security, improved housing and uptake in school attendance among children (Derkyi 2012; Insaidoo et al. 2013; Ros-Tonen et al. 2014). These benefits are however transitory as inter-planting food crops is possible until canopy closure (3 years on average), while long-term timber benefits are subject to risks of theft and wildfire (Ros-Tonen et al. 2014; Acheampong et al. 2016). Measurements of the carbon potential of MTS have been disappointing (Yeboah et al. 2014), but its contribution to climate change adaptation may be promising (Lasco et al. 2014). However, the scheme is still primarily designed to produce timber and, despite an ongoing pilot to introduce shade-tolerant non-timber products ${ }^{3}$, as yet, there is no policy to forge an integrated approach.

\section{Adaptive management and continual learning}

Learning in the MTS usually refers to training in tree planting and seedling production, mainly organized by the

\footnotetext{
3 See http://fcghana.org/treefarm/index.php/about-us, accessed 14 Jan 2017.
}

Forest Services Division in the form of field visits (Insaidoo et al. 2013; Ros-Tonen et al. 2013). Learning has seldom been the result of institutionalized reflection and evaluation, hence does not reflect adaptive management. An exception was the relaunch of the MTS in 2002 that, following stakeholder consultations, drew on the mistakes and disappointments of the colonial taungya system. Current discussions about introducing shade-tolerant species as a way to enhance the livelihood benefits of the scheme hint at a collaborative learning process. Overall, however, continual learning has been limited as the MTS was not designed as an adaptive management system (Ros-Tonen et al. 2014).

\section{Polycentric governance}

The MTS was intended to give greater voice to farmers through the Land Allocation and Taungya Management Committee ('the Taungya Committee') (Acheampong et al. 2016). This committee is responsible for (i) allocating degraded forest reserve land to MTS farmers, (ii) monitoring performance and ensuring compliance of all parties with the contract, and (iii) instituting sanctions and settling disputes (Agyeman et al. 2003). During years of financial support from the African Development Bank (AfDB) to the Community Forest Management Project (between 2002-2010) (which included the MTS), associations or task forces emerged that undertook joint social activities such as alternative livelihood projects; funeral donations to bereaved members; communal labor in pegging and planting; and monitoring theft and fire risks (RosTonen et al. 2013; Osei-Tutu et al. 2015; Acheampong et al. 2016). Occasionally, such associations also designed additional local by-laws to guide the implementation of the MTS (Insaidoo et al. 2013; Ros-Tonen et al. 2013). These rules, however, focused on compliance with, and effective implementation of rules established by the Forestry Commission. In practice, the latter sets the rules regarding tree and food-crop choice and specific farming practices that farmers should use (Derkyi 2012; Ros-Tonen et al. 2014). The MTS Agreement defined by the Forestry Commission stipulates the rules regarding responsibilities, inputs and benefit-sharing (Agyeman et al. 2003; FC 2006). Although the governance structure of MTS encourages links across jurisdictional scales (local authorities, stools, and national government), institutional scales (the constitution, operating rules, by-laws) and spatial scales (from local to national), hybridity and polycentric decision-making within the scheme is hardly recognized. Despite the space for the taungya committees to design locally-specific by-laws, hierarchical governance prevails (Derkyi 2012; Ros-Tonen et al. 2014; Acheampong et al. 2016). Furthermore, polycentric governance is hindered by weak local institutions 
being poorly connected to external organizations (Akamani et al. 2015).

\section{Multi-stakeholder negotiation}

After the failure of the colonial taungya system, the World Bank and the Food and Agricultural Organization of the United Nations (FAO) financed a stakeholder consultation in 2001-2002 during which farmers, communities, land owners and NGOs were consulted on the design of the MTS (Ros-Tonen et al. 2014). This resulted in a redesign of the scheme with more democratic governance and a benefitsharing arrangement that entitles farmers to $40 \%$ of timber proceeds (Marfo 2009). Subsequently, the MTS offers a multi-stakeholder design accommodating the four actor groups outlined in Table 1. Broader partnerships with public actors, donors, NGOS and, in some cases, the private sector were formed where the MTS was implemented under the AfDB-financed Community Forest Management Project (Marfo et al. 2012; Ros-Tonen et al. 2014). However, such partnerships remain dependent on donor funding and space to negotiate the conditions of the scheme or propose a different course remains limited.

\section{Capacity building}

Capacity building in the MTS encompasses training in seedling production and tree planting, with attention to 'alternative livelihoods' (e.g., small livestock rearing) during the years of AfDB support to the community forest management plan. This type of training focuses on transferring skills rather than enhancing farmers' negotiation capacity and empowerment (Insaidoo et al. 2013; Ros-Tonen et al. 2013, 2014).

\section{CREMA}

\section{Integrated approach}

An integrated land-use approach is inherent in CREMA governance: CREMAs attempt to reconcile competing land uses in order to manage trade-offs between human activities and wildlife conservation. Eco-tourism and the exploitation of NTFPs, including wildlife, are popular land uses in this respect, for generating income while (allegedly) preventing the conversion of wildlife habitat into farmland (Agyare et al. 2015a; MLNR 2012). The CREMA concept further supports climate change mitigation and carbon projects (Asare et al. 2013). Creating conservation awareness ranks high in the objectives and is reflected in appreciation of non-economic values concerning wildlife conservation among members (Robinson and Sasu 2013).
Adaptive management and continual learning

The CREMA is built on adaptive management principles, with monitoring and evaluation being "recognized as important aspects of its implementation and development (WD 2000, p. 10). This involves wildlife, trade and trend monitoring to guide management decisions and interventions (Ibid). Asare et al. (2013) argue that its democratic governance structure based on traditional beliefs and values enhances community consensus building, decision-making and problem solving hence adaptive management. How adaptive management materializes on the ground is however hardly documented, the exception being action learning process advocated by IUCN (Barrow et al. 2016; Baruah et al. 2016).

\section{Polycentric governance}

CREMA embodies a paradigm shift from conventional state-run conservation in restricted forests or wildlife reserves to inclusion of local resource users as lead managers of their natural resources. It explicitly embarks on polycentric governance (Agyare 2013) by integrating statutory (Wildlife Division, MLNR) and customary actors (traditional authorities, the Stool) and through decentralization of authority to district-level authorities and devolution of NRM to local CREMA communities. CREMA structures primarily consists of a Community Resource Management Committee (CRMC) and its Executive Committee. The CRMC comprises volunteering farmers and landholders registered to the CREMA, while the Executive Committee comprises CRMC members willing to stand elected by their peers, with roles rotating on a 3-year basis. Members are responsible for steering and overseeing the daily operations and decision-making within the CREMA (Asare et al. 2013), which includes drawing up and enforcing the constitution and by-laws with support from the Wildlife Division and District Assemblies. The latter are important in establishing CREMA constitutions as they offer legislative support and experience during the formation process (WD 2004a). Once the by-laws are recognized by the respective District Assembly, a CREMA is approved by the Wildlife Division and the Ministry of Lands and Forestry (WD 2004a, b; Nyame et al. 2012; Asare et al. 2013). The entire governance process is strongly embedded in local governance and community structures and value systems (Asare et al. 2013). CREMA communities are autonomous in their daily operations; the Wildlife Division and District Assemblies facilitate CREMA communities to set up a constitution and by-laws. The Wildlife Division oversees the CREMA operations and is responsible for renewal of the Certificate of Devolution (WD 2004b). The risk of creating new elites (mainly staff of 
externally funded NGOs) with limited accountability toward local interests has been documented (Baruah 2015), yet within the same cases, action learning has helped overcome such governance issues (Baruah et al. 2016).

\section{Multi-stakeholder negotiation}

Once power is devolved through the Certificate of Devolution, CREMA communities are autonomous in their negotiation and decision-making regarding resource use and conservation activities. Interactions and negotiations are mainly between local level actors, i.e., smallholders, land owners, the CREMA collective and district governments (Agyare et al. 2015b). When external NGOs are involved (e.g., IUCN), links are often established with other relevant actors such as the Administrator of Stool lands, or multistakeholder forums such as the District Forest Forum or Ghana Forest Watch (Nyame et al. 2012).

\section{Stakeholder capacity building}

Capacity building comes through internal objectives of the CREMA itself and may involve the assistance of external institutions, e.g., the Tourism Board and NGOs (Eshun 2010). Popular CREMA activities such as eco-tourism enhance the capacity of community members by engaging in administrative and business management ventures.

\section{Discussion: The Schemes' Alignment with Design Principles for Integrated Landscape Approaches}

All three NRM schemes are embedded within mosaic landscapes of continually interacting land uses, whether through agroforestry systems common throughout Burkina Faso, or a mosaic of forest and wildlife reserves with food (cassava, cocoyam, and plantain) and tree crop farming (cocoa and oil palm) in Ghana. All three landscapes are impacted by deforestation, biodiversity loss, climate change, and persistent poverty-solutions to which may be sought via integrated approaches. However, the CREMA is the only scheme explicitly embarking on multifunctionality and addressing trade-offs between conservation and development aims. This highlights the potential for the CREMA as a potential entry point for implementing integrated approaches.

As far as CAF forests are concerned, there are insufficient linkages between NRM and broader development strategies, despite these forests being historically embedded in multiple land-use mosaics of agroforestry, crop production and agro-pastoralism. Burkina Faso's current poverty alleviation plans prioritize agricultural expansion and intensification, which can exert further pressure on forests and non-agricultural land (Foli and Rabdo 2016). Similar pressures are also present in Ghana, where agricultural policies enhance the expansion of tree crops (Ros-Tonen et al. 2015). In order to overcome such pressures the wider land uses within these mosaic landscapes need to be reconsidered as holistic interacting entities. An example of an entry point for greater integration in Burkina Faso is the clustering of land uses within the same jurisdiction as the CAF forests.

In Ghana, current pilots to integrate shade-tolerant NTFPs and food crops in the MTS and plans to further expand this toward off-reserve areas ${ }^{4}$ signal an important step forward in reconciling timber interests of the Ghana Forestry Commission with farmers' need for short- and midterm income and food security. Institutionalizing these pilots could facilitate an integrated approach toward landscape restoration.

CAF and MTS have seen changes resulting from past failures (Table 2), but again it is only the CREMA that explicitly embarks on adaptive and negotiated management led by local resource users-both in intention (WD 2000) and practice (Baruah et al. 2016). The CAF has transitioned from existing as a donor-funded intervention to a selfsustaining resource co-management scheme through revenue generated from fuelwood exploitation. However, there is no reciprocal flow of information or recognized platform where stakeholders can meet to exchange information or discuss the implications of competing land uses and landscape changes. Furthermore, there are insufficient resources allocated for periodic updating of the conservation of NRM capacity of the CAF technical unit. The MTS slowly progresses toward collaborative learning, e.g., through IUCN's action learning approach (Barrow et al. 2016) or the TREEFARMS project led by the Resource Management Support Center of the Forestry Commission. ${ }^{5}$ However, participants in a workshop held in January 2017 acknowledged that 'procedures to change the bureaucracy are slow' (pers. obs.), meaning that adaptive management and continual learning are not yet institutionalized.

The polycentric governance paradigm has grown out of the co-existence of statutory and customary arrangements, and the influence of globalized policies and interests regarding conservation in response to climate change and unprecedented deforestation (Nagendra and Ostrom 2012; Wyborn and Bixler 2013). All schemes provide for hybrid governance arrangements to accommodate both traditional authorities and community structures and state authority. The CAF and MTS are however primarily co-management schemes where the state (the MEDD in Burkina Faso or the Ghana Forestry Commission) apply the rules of the game.

\footnotetext{
$\overline{4}$ See http://fcghana.org/treefarm/ accessed 3 Feb 2017.

5 See http://fcghana.org/treefarm/ accessed 3 Feb 2017.
} 
CREMA communities are autonomous in their decisions once they receive their certificate of devolution. Strong links exist with other centers of decision-making such as the District Assemblies and the Wildlife Division at national level. International connections are growing with increasing donor funding and technical support from NGOs like the IUCN, while both the MTS and CREMA attracted international interest for their potential to serve as REDD pilot cases (Agidee 2011; Kalame et al. 2011; Asare et al. 2013).

All schemes are characterized by a multi-stakeholder design, but only the CREMA has institutional arrangements in place that allow for negotiated goals and change logic. The CAF and MTS are characterized by rather rigid decision-making structures in which state organizations have the biggest influence. Although CREMA's institutional design is such that it accommodates negotiations, these are restricted to the local CREMA level. Where national and international NGOs engage in the scheme, links are established with platforms like District Forest Forums and the national-level civil society coalition Forest Watch Ghana (Nyame et al. 2012).

To participate effectively in NRM and respond to landscape dynamics, platforms are needed to exchange knowledge and experiences (Sayer et al. 2016; Ros-Tonen et al. 2015). No such platforms are in place in any of the schemes; the CAF and CREMA depend on NGOs for capacity building, and where capacity building occurs in the MTS it is restricted to seedling production and tree planting, rather than targeting improved learning capacity and negotiation skills (Opoku-Boamah and Takayoshi 2011). In the same way, assessments of the socio-economic performance of the scheme are scarce (ibid.).

Based on the scoring in Table 3, Fig. 1 indicates how these schemes are currently aligned with the principles of landscape approaches. This study did not set out to use the principles as a box-ticking exercise, but to identify the strengths and weaknesses when the schemes are considered as entry points for landscape approaches.

\section{Conclusion}

This paper explored whether, and how, three NRM initiatives in Ghana and Burkina Faso that integrate landscape and livelihood objectives of local populations can provide entry points for the implementation of integrated landscape approaches. We explored this potential by analyzing the extent to which the three schemes-the CAF in Burkina Faso, the MTS and CREMA in Ghana-align with some key design principles for integrated landscape approaches. Based on the analysis, the CREMA approach in Ghana provides the most promising entry point for implementing a landscape approach and shows how such an approach could be operationalized. However, its scale and multilevel connectedness may be too limited to guarantee effective landscape governance beyond the CREMA territory and would require up- or side-scaling, e.g., by linking several CREMAs to increase the scale of operation or by linking the CREMA to broader stakeholder coalitions (Nyame et al. 2012).

Inversely, based on their scale, the CAF and MTS represent potential integrated landscape approaches in which different and often competing land uses are interacting with one another. These interactions, as we have shown, are either through the fluid movement of actors across land uses in fulfilling livelihood objectives (CAF) or through the inherent re-design of the scheme to enable farmers to benefit from resource management efforts (the MTS).

Improving the interconnectedness of land uses in the CAF requires platforms of collective deliberation on issues of rural development, resource governance and climate change in which different land users are represented. This will reflect the reality of how rural actors utilize and preserve natural resources on the ground.

A lack of long-term funding and economic incentives threaten the durability of the MTS, while hierarchical governance arrangements impede a genuine transformation toward collaborative decision-making, power sharing and institutional diversity (Ros-Tonen et al. 2014). Only if the lessons from collaborative learning processes such as in the TREEFARMS project are internalized and rolled out, are there prospects for evolving into an adaptive and learning scheme that is open to integrated and multi-stakeholder approaches at the landscape level.

Concrete monitoring and evaluation mechanisms are key features missing from all three schemes. Monitoring contributes to identifying weaknesses within NRM schemes through evaluation of their biodiversity, economic sustainability, and social relevance (Lovell and Johnston 2009). The importance of monitoring has further relevance since all of three schemes have been established as a response to failure of past conservation strategies. A landscape approach to NRM includes a continual learning and adaptive management cycle that enables actors to respond to changes in the natural resource base (Sayer et al. 2013).

The types of knowledge deemed relevant in NRM schemes can influence the level of involvement of local user groups who often possess locally specific knowledge (Clark et al. 2016). Often, state forestry and land-use planning institutions conduct conservation programs based on universal scientific knowledge. Only the CREMA initiative in Ghana explicitly mentions the importance of local knowledge and practices for the conservation and sustainable use of natural resources. In this respect, we argue for platforms of knowledge exchange between different knowledge systems and governance levels (c.f. Ros-Tonen et al. 2015). 


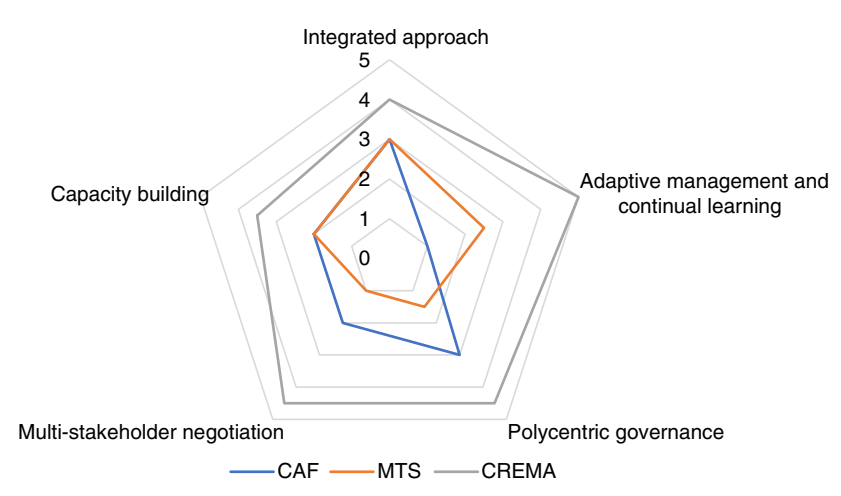

Fig. 1 Alignment of the NRM schemes with principles for integrated landscape approaches

Such platforms can act as catalyzers by providing "an arena for knowledge co-production, trust building, sense making, learning, vertical and horizontal collaboration and conflict resolution" (Berkes 2009, p. 1695). Accommodating such platforms requires organizational and institutional flexibility to provide space for informal knowledge brokering, experimental learning, and iterative approaches. This flexibility seems to be the greatest challenge, although the CREMA approach in Ghana provides glimmers of hope.

Acknowledgements Financial support from the Center for International Forestry Research (CIFOR) under the framework of the Conservation and Sustainable use of Tropical Forest Biodiversity program financed by the United States Agency for International Development (USAID) and from the Applied Research Fund of WOTRO Science for Global Development (Project W 08.270.324) for the "TREEFARMS" project is gratefully acknowledged. The authors are additionally grateful to colleagues in Burkina Faso, Ghana and Indonesia who provided relevant comments and contributions to this paper. The authors thank two anonymous reviewers for their constructive comments to an earlier version of this paper.

\section{Compliance with Ethical Standards}

Conflict of Interest The authors declare that they have no conflict of interest.

Open Access This article is distributed under the terms of the Creative Commons Attribution 4.0 International License (http://crea tivecommons.org/licenses/by/4.0/), which permits unrestricted use, distribution, and reproduction in any medium, provided you give appropriate credit to the original author(s) and the source, provide a link to the Creative Commons license, and indicate if changes were made.

\section{References}

Acheampong E, Insaidoo TF, Ros-Tonen MAF (2016) Management of Ghana's modified taungya system: challenges and strategies for improvement. Agrofor Syst 90:659-674

Agbor T, Tanyi F (2015) Sustainability of community forest management in Burkina Faso: the Case of CAF Cassou. Master Thesis. University of Helsinki
Agidee Y (2011) Forest carbon in Ghana: spotlight on community resource management areas. Forest Trends, Washington, DC

Agyare AK (2013) Polycentric governance and social-ecological performance of community resource management areas in Ghana. PhD Dissertation, University of Victoria https://dspace. library.uvic.ca/handle/1828/4930?show=full. Accessed $15 \mathrm{Jul}$ 2016

Agyare AK, Murray G, Dearden P, Rollins R (2015a) Conservation in context: variability in desired and perceived outcomes of community based natural resources governance in Ghana. Soc Nat Resour 28(9):975-994

Agyare AK, Murray G, Dearden P, Rollins R (2015b) Understanding inter-community performance assessments in community-based resource management at Avu Lagoon, Ghana. Environ Dev Sustain 17:1493-1508

Agyeman V, Marfo K, Kasanga K, Danso E, Asare A, Yeboah O, Agyeman F (2003) Revising the taungya plantation system: new revenue-sharing proposals from Ghana. Unasylva 54:40-43

Agyeman V (2006) Promoting smallholder plantations in Ghana. Arborvitae 31:6

Akamani K, Wilson PI, Hall TE (2015) Barriers to collaborative forest management and implications for building the resilience of forestdependent communities in the Ashanti region of Ghana. J Environ Manage 151:11-21

Appiah M, Blay D, Damnyag L, Dwomoh FK, Pappinen A, Luukkanen O (2009) Dependence on forest resources and tropical deforestation in Ghana. Environ Dev Sustain 11:471-487

Arbonnier M (2004) Trees, shrubs and lianas of West African dry zones. CIRAD, Margraf Publishers GMBH, MNHN, Paris

Arevalo J (2016) Improving woodfuel governance in Burkina Faso: the experts' assessment. Renew Sustain Energy Rev 57:1398-1408

Armitage D (2005) Adaptive capacity and community-based natural resource management. Environ Manage 6:703-715

Armitage D, Marschke M, Plummer R (2008) Adaptive co-management and the paradox of learning. Glob Environ Change 18:86-98

Asare RA, Kyei A, Mason JJ (2013) The community resource management area mechanism: a strategy to manage African forest resources for REDD+. Philos Trans R Soc B 368:20120311

Balint PJ, Stewart RE, Desai A, Walters LC (2011) Wicked environmental problems: managing uncertainty and conflict. Island Press, Washington/Covelo/London

Barrow E, Walters G, Nakangu B, Bobtoya S, Cruz R, Kutegeka S, Angu Angu K, Savadogo M. (2016) RFGI Handbook II: implementing improved natural resource governance in practice: an action learning handbook for Sub-Saharan Africa. Responsive Forest Governance Initiative Working Paper No. 35. IUCN, University of Illinois, and the Council for the Development of Social Science Research in Africa. CODESRIA, Dakar

Baruah M (2015) Effect of institutional choices on representation in a community resource management area in Ghana. RFGI Working Paper 22. CODESRIA, Dakar. https://sdep.earth.illinois.edu/files/ RFGI_Working_Papers/RFGI\%2022_Baruah.pdf Accessed 3 Feb 2017

Baruah M, Bobtoya S, Mbile P, Walters G (2016) Governance of restoration and institutions: working with Ghana's community resource management areas. World Dev Perspect 3:38-41

Bele MY, Sonwa DJ, Tiani A-M (2015) Adapting the Congo Basin forests management to climate change: linkages among biodiversity, forest loss, and human well-being. For Policy Econ 50:1-10

Benhin JK, Barbier EB (2004) Structural adjustment programme, deforestation and biodiversity loss in Ghana. Environ Resour Econ 27:337-366

Berkes F (2009) Evolution of co-management: role of knowledge generation, bridging organizations and social learning. J Environ Manage 90:1692-1702 
Blay D, Appiah M, Damnyag L, Dwomoh FK, Luukkanen O, Pappinen A (2008) Involving local farmers in rehabilitation of degraded tropical forests: some lessons from Ghana. Environ Dev Sustain 10:503-518

Boffa J-M (1999) Agroforestry Parklands in Sub-Saharan Africa. FAO Conservation Guide 34, December 1999. Agrofor Syst 50:169-170

Chia EL, Sufo RK (2016) A situational analysis of Cameroon's technical operation units (TOUs) in the context of the landscape approach: critical issues and perspectives. Environ Dev Sustain 18:951-964

Clark WC, Van Kerkhoff L, Lebel L, Gallopin GC (2016) Crafting usable knowledge for sustainable development. PNAS 113 (17):4570-4578

Coulibaly-Lingani P, Savadogo P, Tigabu M, Oden P (2011) Decentralization and community forest management in Burkina Faso: constraints and challenges. Int For Rev 13:476-486

DeFries R, Rosenzweig C (2010) Toward a whole-landscape approach for sustainable land use in the tropics. PNAS 107(46):19627-19632

Derkyi MAA (2012) Fighting over forest. Interactive governance of conflicts over forest and tree resources in Ghana's high forest zone. African Studies Centre, Leiden

Dietz T, Ostrom E, Stern PC (2003) The struggle to govern the commons. Science 302:1907-1912

Eade D (2007) Capacity building: who builds whose capacity? Dev Pract 17(4):630-639

Eshun G (2010) Ecotourism development in Ghana: a postcolonial study with focus on Boabeng-Fiema Monkey Sanctuary and Kakum National Park. PhD thesis, University of Leicester

Etongo D, Djenontin INS, Kanninen M, Fobissie K (2015) Smallholders' tree planting activity in the Ziro Province, Southern Burkina Faso: impacts on livelihood and policy implications. Forests 6:2655-2677

Fakuda-Parr S, Lopes C (2013) Capacity for development: new solutions to old problems. Routledge, London

FAO (2015) Global forest resources assessment 2015. Food and Agriculture Organization of the United Nations, Rome

Forestry Commission (FC) (2006) National forest plantation development programme: the modified taungya system. Forestry Commission, Government of Ghana, Accra, Ghana

Forestry Commission (FC) (2015) National forest plantation development programme 2015 annual report. http://www.fcghana.org/ userfiles/files/Plantation\%20Annual\%20Report/2015\% 20ANNUAL\%20REPORT\%20(2).pdf. Accessed 3 Feb 2017

Foli S, Rabdo A (2016) Drivers and outcomes of changing land use in parkland agroforestry systems of central Burkina Faso. In: Deakin EL, Sunderland TCH, Kshatriya M (eds) Agrarian change in tropical landscapes. CIFOR, Bogor, pp 269-299

Folke C, Hahn T, Olsson P, Norberg J (2005) Adaptive governance of social-ecological systems. Annu Rev Environ Resour 30:441-473

Foster-Fishman PG, Berkowitz SL, Lounsbury DW, Jacobson S, Allen NA (2001) Building collaborative capacity in community coalitions: a review and integrative framework. Am J Commun Psychol 29(2):241-261

Gautier D, Garcia C, Negi S, Wardell DA (2015) The limits and failures of existing forest governance standards in semi-arid contexts. Int For Rev 17:114-126

Gupta J, Termeer C, Klostermann J, Meijerink S, Van den Brink M, Jong P, Nooteboom S, Bergsma E (2010) The adaptive capacity wheel: a method to assess the inherent characteristics of institutions to enable the adaptive capacity of society. Environ Sci Policy 13:459-471

Hart AK, Milder JC, Estrada-Carmona N, DeClerck FAJ, Harvey CA, Dobie P (2014) Integrated landscape initiatives in practice: assessing experiences from 191 landscapes in Africa and Latin America. In: Minang PA, van Noordwijk M, Freeman OE, Mbow C, de Leeuw J, Catacutan D (eds) Climate-smart landscapes: multifunctionality in practice. World Agroforestry Centre (ICRAF), Nairobi, pp 89-101

Harvey CA, Komar O, Chazdon R, Ferguson BG, Finegan B, Griffith DM, Martínez-Ramos R, Morales H, Nigh R, Soto-Pinto L, Van Breugel M, Wishnie M (2008) Integrating agricultural landscapes with biodiversity conservation in the Mesoamerican hotspot. Conserv Biol 22(1):8-15

Hilson G (2012) The environmental impact of small-scale gold mining in Ghana: identifying problems and possible solutions. Geogr J 168(1):57-72

Ickowitz A, Powell B, Salim MA, Sunderland TCH (2014) Dietary quality and tree cover in Africa. Glob Environ Change 24:287-294

Insaidoo TF, Ros-Tonen MA, Acheampong E (2013) On-farm tree planting in Ghana's high forest zone: The need to consider carbon payments. In: Rival L, Muradian R (eds) Governing the Provision of Ecosystem Services. vol 4. Springer, pp 437-463

Kabore C, Ouedraogo K (2000) Case study 1: the Nazinon reserved forest (Burkina Faso). In: Bellfontaine R, Gaston A, Petrucci Y (eds) Management of natural forests of dry tropical zones. FAO Conservation Guide 32. FAO, Rome, pp 225-242

Kalame FB (2009) The modified taungya system in Ghana's transitional zone. In: van Bodegom AJ, Savenije H, Wit M (eds) Forests and Climate Change: adaptation and mitigation. Tropenbos International, Wageningen, The Netherlands

Kalame FB, Aidoo R, Nkem J, Ajayie OC, Kanninen M, Luukkanen O, Idinoba M (2011) Modified taungya system in Ghana: a win-win practice for forestry and adaptation to climate change? Environ Sci Policy 14:519-530

Koffi CK, Djoudi H, Gautier D (2016) Landscape diversity and associated coping strategies during food shortage periods: evidence from the Sudano-Sahelian region of Burkina Faso. Reg Environ Change 16:1-12

Kozar R, Buck L, Barrow EG, Sunderland TCH, Catacutan DE, Planicka C, Hart AK, Willemen L (2014) Toward viable landscape governance systems: what works? EcoAgriculture Partners, on behalf of the Landscapes for People, Food, and Nature Initiative, Washington, DC

Ky-Dembele C, Tigabu M, Bayala J, Ouédraogo SJ, Odén PC (2007) The relative importance of different regeneration mechanisms in a selectively cut savanna-woodland in Burkina Faso, West Africa. For Ecol Manage 243:28-38

Lasco RD, Delfino RJP, Espaldon MLO (2014) Agroforestry systems: helping smallholders adapt to climate risks while mitigating climate change. WIREs Clim Change 5:825-833

Lebel L, Anderies JM, Campbell B, Folke C, Hatfield-Dodds S, Hughes TP, Wilson J (2006) Governance and the capacity to manage resilience in regional social-ecological systems. Ecol Soc $1: 11$

Lovell ST, Johnston DM (2009) Designing landscapes for performance based on emerging principles in landscape ecology. Ecol Soc 14:44

Mantyka-Pringle CS, Visconti P, Di Marco M, Martin TG, Rondinini C, Rhodes JR (2015) Climate change modifies risk of global biodiversity loss due to land-cover change. Biol Conserv 187:103-111

Marfo E (2009) Security of tenure and community benefits under collaborative forest management arrangements in Ghana: a country report. CSIR-INSTI, Accra

Marfo E, Acheampong E, Opuni-Frimpong E (2012) Fractured tenure, unaccountable authority, and benefit capture: constraints to improving community benefits under climate change mitigation schemes in Ghana. Conserv Soc 10:161

Ministry of the Environment and Sustainable Development (MEDD) (2012) Readiness preparation plan for REDD (R-PP-Burkina Faso). https://www.forestcarbonpartnership.org/sites/forestca rbonpartnership.org/files/Documents/PDF/June2012/R-PP\% 
20Burkina\%20English-\%20FINAL\%20June\%202012.pdf.

Accessed 3 Feb 2017

MLNR (Ministry of Lands and Natural Resources) (2012) Ghana forest and wildlife policy. Ministry of Lands and Natural Resources, Accra. https://s3.amazonaws.com/ndpc-static/pubica tion/Forest+and+Wildlife+Policy_2012.pdf. Accessed 15 Jul 2016

Minang PA, van Noordwijk M, Freeman OE, Mbow C, de Leeuw J, Catacutan D (2014) Climate-smart landscapes: multifunctionality in practice. World Agroforestry Centre (ICRAF), Nairobi

Murphree M (2008) Community resource management areas (CREMA): a review of progress and implementation in the Western Region of Ghana. Wildlife Division, Forestry Commission, Accra

Nagendra H, Ostrom E (2012) Polycentric governance of multifunctional forested landscapes. Int J Commons 6(2):104-133

Nyame SK, Okai M, Adeleke A, Fisher R (2012) Small changes for big impacts: lessons for landscapes and livelihoods from the Wassa Amenfi West Landscape, Ghana. IUCN, Gland

Opoku-Boamah NC, Takayoshi S (2011) Evaluation of farmers in reforestation of degraded reserve: a case study of Kyekyewere community in a transitional Zone of Ghana. J Agric Sci Tokyo Univ Agric 56:9-16

Osei-Tutu P, Pregernig M, Pokorny B (2015) Interactions between formal and informal institutions in community, private and state forest contexts in Ghana. For Policy Econ 54:26-35

Ouedraogo I (2006) Land use dynamics in Bieha district, Sissili province; southern Burkina Faso, West Africa. UMOJA 1:18-34

Ouédraogo B (2007) Filière bois d'énergie burkinabé: structuration des prix et analyse de la répartition des bénéfices. Bois For Trop 294:75-88

Ouédraogo B (2009) Aménagement forestier et lutte contre la pauvreté au Burkina Faso. développement durable et territoires. doi:10.4000/ developpementdurable.8215

Ouedraogo I, Savadogo P, Tigabu M, Cole R, Odén P, Ouadba JM (2009) Is rural migration a threat to environmental sustainability in Southern Burkina Faso? Land Degrad Dev 20:217-230

Ouedraogo I, Tigabu M, Savadogo P, Compaoré H, Odén PH, Ouadba JM (2010) Land cover change and its relation with population dynamics in Burkina Faso, West Africa. Land Degrad Dev $21: 453-462$

Pahl-Wostl C (2015) Water governance in the face of global change. From understanding to transformation. Springer International Publishing, Cham/Heidelberg/New York/Dordrecht/London, pp 99-124

Pahl-Wostl CA (2009) A conceptual framework for analysing adaptive capacity and multi-level learning processes in resource governance regimes. Glob Environ Change 3:354-365

Paletto A, De Meo I, Ferretti F (2011) Participatory governance in forest landscape planning: an application in southern Italy. Silva Lusit 19(2):149-163

Paré S, Söderberg U, Sandewall M, Ouadba JM (2008) Land use analysis from spatial and field data capture in southern Burkina Faso, West Africa. Agric Ecosyst Environ 127:277-285

Phelps J, Webb EL, Agrawal A (2010) Does REDD+ threaten to recentralize forest governance? Science 328:312-313

Pouliot M, Treue T (2013) Rural people's reliance on forests and the non-forest environment in West Africa: evidence from Ghana and Burkina Faso. World Dev 43:180-193

Reed J, Deakin L, Sunderland T (2015) What are 'integrated landscape approaches' and how effectively have they been implemented in the tropics: a systematic map protocol. Environ Evid 4:1-7

Reed J, Van Vianen J, Deakin EL, Barlow J, Sunderland T (2016) Integrated landscape approaches to managing social and environmental issues in the tropics: learning from the past to guide the future. Glob Change Biol 22:2540-2554
Reed J, Van Vianen J, Barlow J, Sunderland T (2017) Have integrated landscape approaches reconciled societal and environmental issues in the tropics? Land Use Policy 63:481-492

Robinson LW, Bennett N, King LA, Murray G (2012) "We want our children to grow up to see these animals:" values and protected areas governance in Canada, Ghana and Tanzania. Hum Ecol 40:571-581

Robinson LW, Sasu KA (2013) The role of values in a communitybased conservation initiative in northern Ghana. Environ Value 22:647-6664

Ros-Tonen MAF, Insaidoo TFG, Acheampong E (2013) Promising start, bleak outlook: the role of Ghana's modified taungya system as a social safeguard in timber legality processes. For Policy Econ 32:57-67

Ros-Tonen MAF, Derkyi M, Insaidoo TF (2014) From comanagement to landscape governance: whither Ghana's modified taungya system? Forests 5(12):2996-3021

Ros-Tonen MAF, Van Leynseele BY-P, Laven A, Sunderland T (2015) Landscapes of social inclusion: inclusive value-chain collaboration through the lenses of food sovereignty and landscape governance. Eur J Dev Res 27:523-540

Sachs JD, Baillie JE, Sutherland WJ, Armsworth PR, Ash N, Beddington J, Blackburn TM, Collen B, Gardiner B, Gaston KJ (2009) Biodiversity conservation and the millennium development goals. Science 325:1502-1503

Sawadogo L (2007) Adapter les approches de l'amenagement durable des forets seches aux aptitudes sociales, economiques et technologiques en Afrique: le cas du Burkina Faso. CIFOR, Bogor

Sawadogo L, Tiveau D (2011) Twenty years of experience of joint forest management in Burkina Faso. Paper presented at the Sustainable forest management in Africa Symposium, Stellenbosch, South Africa. Accessed 3-7 Nov 2008

Sayer J, Sunderland T, Ghazoul J, Pfund J-L, Sheil D, Meijaard E, Venter M, Boedhihartono AK, Day M, Garcia C, Van Oosten C, Buck LE (2013) Ten principles for a landscape approach to reconciling agriculture, conservation, and other competing land uses. PNAS 110(21):8349-8356

Sayer J, Endamana D, Boedhihartono AK, Ruiz-Perez M, Breuer T (2016) Learning from change in the Sangha tri-national landscape. Int For Rev 18:130-139. doi:10.1505/146554816819683771

Scherr SJ, Shames S, Friedman R (2012) From climate-smart agriculture to climate-smart landscapes. Agric Food Secur 1(1):1

Sunderland TCH, Baudron F, Ickowitz A, Padoch C, Ros-Tonen MAF, Sandbrook C, Vira B, Chambers J, Deakin EL, Foli S, Jeary K, Parrotta JA, Powell B, Reed J, Ogalleh SA, Neufeldt H, Serban A (2015) Response options across the landscape. In: Vira B, Wildburger C, Mansourian S (eds) Forests and food: addressing hunger and nutrition across sustainable landscapes. Open Book Publishers, Cambridge, MA, pp 183-209

TREEFARMS Project (2017) Annual progress report for the Food \& Business Applied Research Fund. Internal Report (unpublished internal report)

Virji H, Padgham J, Seipt C (2012) Capacity building to support knowledge systems for resilient development: approaches, actions, and needs. Curr Opin Environ Sustain 4(1):115-121

Westholm L, Kokko S (2011) Prospects for REDD+: local forest management and climate change mitigation in Burkina Faso. Focali Report No 2011:01. Gothenburg

Westholm L (2016) Fruits from the forest and the fields: forest conservation policies and intersecting social inequalities in Burkina Faso's REDD+program. Int For Rev 18:511-521

WD (Wildlife Division) (2000) Wildlife division policy for collaborative community based wildlife management. Forestry Commission http://www.fcghana.org/library.php?id=19. Accessed 15 Jul 2016 
WD (Wildlife Division) (2004a) A briefing document on collaborative resource management in Ghana. Forestry Commission. http:// www.fcghana.org/library.php?id=19. Accessed $15 \mathrm{Jul} 2016$

WD (Wildlife Division) (2004b) A user manual on how to start and operate a community resource management area. Forestry Commission. http://www.fcghana.org/library.php?id=19. Accessed 15 Jul 2016
Wyborn C, Bixler RP (2013) Collaboration and nested environmental governance: scale dependency, scale framing, and cross-scale interactions in collaborative conservation. J Environ Manage 123:58-67

Yeboah D, Burton AJ, Storer AJ, Opuni-Frimpong E (2014) Variation in wood density and carbon content of tropical plantation tree species from Ghana. New For 1:35-52 